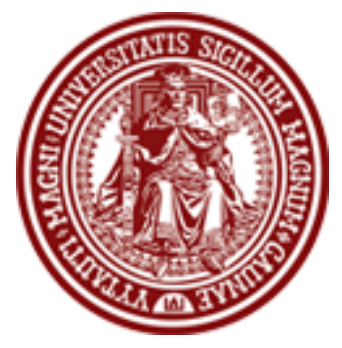

BALTIC JOURNAL OF LAW \& POLITICS

VOLUME 4, NUMBER 1 (2011)

ISSN 2029-0454

http://www.versita.com/bjlp

Cit.: Baltic Journal of Law \& Politics 4:1 (2011): 1-26

DOI: $10.2478 / \mathrm{v} 10076-011-0001-8$

\title{
INVOLVEMENT OF NON-EU EUROPEAN NATO MEMBERS IN CSDP: THE TURKISH CASE
}

\author{
Şeyda Hanbay \\ Doctoral Candidate \\ Vytautas Magnus University Faculty of Political Sciences and Diplomacy \\ (Lithuania) \\ Career Diplomat (currently Second Secretary) at the Ministry of Foreign \\ Affairs of the Republic of Turkey

\section{Contact information} \\ Address: Turkish Embassy, Didžioji str. 37, LT-01128 Vilnius, Lithuania \\ Phone: (+370 5) 2649572 \\ E-mail address: hanbay.seyda@hotmail.com
}

Received: March 04, 2011; reviews: 2; accepted: May 26, 2011.

\section{ABSTRACT}

The European Union (EU) has been building its security and defense policy since the 1990s. The evolution of the Common Security and Defence Policy (CSDP) process has affected the non-EU European NATO members' position in the European security architecture. The differences in the compositions of NATO and EU members have created undesired issues. As a staunch NATO member and an accession country to the EU, Turkey has also been affected by the developments in the CSDP. This article takes Turkey as a case study in analyzing the state of affairs of the involvement of non-EU European NATO members in the CSDP.

\section{KEYWORDS}

NATO, EU, CSDP, Turkey, non-EU European NATO members, participation, WEU

\section{NOTE}

Views expressed in the paper represent the author's own assessments. 


\section{INTRODUCTION}

This article seeks to answer the main question of whether the modalities of involving non-EU European NATO members in CSDP $^{1}$ activities have been fulfilled. The research question is related with the intergovernmental nature of the CSDP. The article studies Turkey's case in order to answer this question. The reason why compliance with the principles of involving non-EU European NATO members in CSDP activities is studied through analyzing Turkey's case can be summarized as follows. Institutionalizing of the CSDP has mostly affected Turkey as a non-EU European NATO member. Turkey is a strong supporter and a leading contributor of the CSDP operations. Turkey has taken part in all of the Berlin Plus operations and all the CSDP activities to which it has been invited. Turkey is the biggest non-EU contributor to the CSDP activities. Most of these activities occur in the vicinity of Turkey. However, the evolution of the CSDP process has adversely affected Turkey's position in the European security architecture and led to its exclusion from the decision-making process. Because of this, the Turkish arguments regarding involvement in CSDP activities raise attention and the reasons behind these arguments are worth elaborating. This study concentrates on the period from the early 1990 s to today.

The article also argues that the level of involvement of non-EU NATO members in CSDP activities affects the balance on which NATO-EU relations are established. The main question is closely linked with NATO-EU cooperation since the EU's stance on the involvement of non-EU NATO members, including Turkey, bears direct results over this cooperation. To this end, particular attention is given to this cooperation. The EU's desire to use NATO assets and capabilities for its operations within the framework of the CSDP has affected relations from the beginning. The CSDP has become a common concern of both NATO and the EU. During the process of institutionalizing NATO-EU cooperation Turkish policies came to the forefront. This article also attempts to refute the misleading claim put forward by some circles that Turkey is blocking NATO-EU cooperation.

This analysis is important for several reasons. Firstly, existent shortcomings in the involvement of non-EU European NATO members in CSDP activities and the ways of developing NATO-EU cooperation should be dealt with without delay. The security realities of our day require maximizing collective efforts to this end. Concrete proposals in this field are required. Secondly, Turkey has come to the

\footnotetext{
${ }^{1}$ With the entry into force of Lisbon Treaty on 1 December 2009, the European Security and Defence Policy (ESDP) was renamed as Common Security and Defence Policy (CSDP). In this article I will refer to the term ESDP where necessary.
} 
center stage by the current global challenges and Turkish policies continue to receive greater and greater attention. This country's security and foreign policy preferences worth to dwell on, as the security challenges around Turkey are of a global nature. In this vein, updated scholarly works are needed. The role of Turkey in European security is usually connected with the country's NATO membership. However, Turkey's place in the EU's CSDP is often neglected. Similarly, Turkey's role in NATO-EU cooperation is also not understood clearly. The academic works in this field are rather limited. This study is a modest attempt in adding the existing literature in this sense.

This article consists of three sections. The first section analyses the background of the 'participation issue' of non-EU European NATO countries in CSDP activities by concentrating on the case study of Turkey. The second section dwells on the approach of the EU to the acquis established for the involvement of non-EU European NATO members in CSDP through the Turkish case. The final section studies reflections of the 'participation issue' on NATO-EU cooperation. Case Study strategy is applied as the research method. The empirical material for this study consists of official EU and NATO documents, statements and speeches by relevant officials, press releases of related public institutions, newspaper articles and academic works by relevant scholars. Discourses either written or spoken constitute the backbone of this work.

\section{THE CORE OF THE PROBLEM}

CSDP is intergovernmental and organized in the second pillar within a largely supranational European Union. ${ }^{2}$ Although the essential intergovernmental nature of decision-making in relation to CFSP and CSDP looks set to prevail with the Lisbon Treaty, nevertheless there are new provisions to facilitate that process in a Union of 27 Member States. By granting the Union a legal personality (ToL, Article 46A) for the first time, the Lisbon Treaty enables it to sign treaties or international agreements towards which it has actively participated in the elaboration and negotiation. Among the various new provisions contained in the Lisbon Treaty, many do not challenge the essential inter-governmental nature of foreign and security policy decision making. ${ }^{3}$

Since the enlargement of NATO and the EU in 2004 and the accession of Bulgaria and Romania to the European Union in 2007, these organizations have 21

\footnotetext{
${ }^{2}$ Margriet Drent and Dick Zandee, Breaking Pillars: Towards a Civil-Military Security Approach For the European Union (Netherlands: Cligendeal Institute, 2010), p. 14 // http://www.clingendael.nl/publications/2010/20100211_breaking_pillars.pdf (accessed April 17, 2011). 3 Sophie Dagand, "The impact of the Lisbon Treaty on CFSP and ESDP," European Security Review No. 37 (March 2008) // http://www.isis-europe.org/pdf/2008_artrel_150_esr37tol-mar08.pdf (accessed April 17, 2011).
} 
member countries in common. Canada, Iceland, Norway, Turkey, Albania, Croatia and the United States, which are members of NATO but not of the EU, participate in all NATO-EU meetings. So do Austria, Finland, Ireland, Sweden, and since 2008, Malta, which are members of the EU and of NATO's Partnership for Peace (PfP) programme. ${ }^{4}$ The mismatch between the compositions of these two organizations and the question of how to involve non-EU NATO members in ESDP (referred to as "the participation issue" in NATO jargon) has affected relations from the start. As with any multifaceted international matter, there is more than one national or institutional agenda at stake. ${ }^{5}$ The 'participation issue' has been on the agenda since the outset of the arrangements regarding the involvement of non-EU European Allies. Then Turkish Minister of Foreign Affairs H.E. Ismail Cem's remarks expressed in 2001 are worth noting here. Cem stated in Luxembourg on 26 June 2001:

NATO-EU co-operation is slowly but surely gathering pace and will continue to do so. However, the important issue of participation, which is one of the defining dimensions of the whole process, is yet to be resolved, even though there has recently been some progress. A solution is within our grasp if all the involved parties continue to display the foresight and flexibility. ${ }^{6}$

Currently the 'participation issue' is also one of the main items in the interaction between NATO and the EU.

As Ihsan Kiziltan states the Alliance gave its blessing to ESDP through the Washington Summit of 1999. Paragraph 9.d of the Washington Summit Communique reads as: "We attach utmost importance to ensuring the fullest possible involvement of non-EU European Allies in the EU-led crisis response operations, building on existing consultation arrangements within the WEU." ${ }^{\prime 7}$ Subsequently, at the Nice European Council held in December 2000, the EU set out the arrangements regarding the involvement in ESDP of non-EU European members (at the time Norway, Iceland, and Turkey) and candidates for accession to the EU, as well as the standing arrangements for consultations and cooperation between the EU and NATO. However, the practical details of these arrangements for the involvement of non-EU European Allies in ESDP had to be elaborated in a further round of discussion. This process required intensive negotiations between the main national actors, namely the UK, U.S.A, Greece and Turkey as well as the EU and

\footnotetext{
4 "NATO-EU: a Strategic Partnership" // http://www.nato.int/cps/en/natolive/topics_49217.htm (accessed July 1, 2010).

${ }^{5}$ Ihsan Kiziltan, "Improving the NATO-EU Partnership: A Turkish Perspective," Turkish Policy Quarterly Vol. 7, No. 3 (2008): 34.

6 "Statement By H.E. Mr. İsmail Cem June 26, 2001 - Luxembourg" //

http://www.mfa.gov.tr/_p_statement-by-h_e_-mr_-ismail-cem_br_june-26_-2001-

luxembourg____.en.mfa (accessed July 19, 2010).

7 "NATO's Washington Summit Communique" (April 24, 1999) // http://www.nato.int/docu/pr/1999/p99064e.htm (accessed June 13, 2010) (italics - SH).
} 
NATO staffs. Referred to initially as the "Ankara", then the "Brussels" document, eventually what became known as the "Nice implementation document" was approved at the Brussels European Council on 24-25 December 2002. ${ }^{8}$

The 'Annex II' of the Brussels European Council Presidency Conclusions of 2425 October 2002 under the title "ESDP: Implementation of the Nice Provisions on the Involvement of the Non-EU European Allies" sets the modalities for involving non-EU European NATO members in CSDP activities. The document is widely known as the 'Nice Implementation Document'. ${ }^{9}$ The Nice Implementation Document cleared the modalities for participation in EU-led operations by making a distinction between an "EU-led operation using NATO assets and capabilities" and "EU-led operation not requiring recourse to NATO assets and capabilities" (para.11 and 12.). ${ }^{10}$

The Nice Implementation Document opened the way for NATO and the EU to reach an agreement based on the North Atlantic Council (NAC) decision of 13 December 2002 and the NATO-EU Joint Declaration of 16 December 2002 on the establishment of the NATO-EU strategic partnership. ${ }^{11}$ The modalities of NATO-EU cooperation were established in the year 2003 through a mutually agreed set of documents and they constitute the "agreed framework" of NATO-EU relations. The agreed framework for the 'Strategic Partnership' between NATO and EU was established in 2003 with an exchange of letters and consists of the Berlin Plus agreements, the NAC Decision of 13 December 2002 and the Nice Implementation Document. The NAC Decision of 13 December 2002 is particularly important since it clearly states that NATO-EU relations go beyond the Berlin Plus arrangements and cover NATO-EU strategic cooperation as well.

The NATO-EU partnership was given due attention in NATO's new Strategic Concept adopted in 2010 and non-EU NATO members' fullest involvement in strategic partnership between NATO and the EU is deemed essential. The relevant part of the new strategic concepts reads as follows: "... Non-EU Allies make a significant contribution to these efforts. For the strategic partnership between NATO and the EU, their fullest involvement in these efforts is essential (para. 28)."12 This wording on the non-EU NATO members' involvement in the strategic partnership

\footnotetext{
8 Ihsan Kiziltan, supra note 5: 35.

9 "ESDP: 'Implementation of the Nice Provisions on the Involvement of the Non-EU European Allies'," The Brussels European Council, Presidency Conclusions, Annex II (October 24-25, 2002).

10 Ibid., para. 11 \& 12.

11 "European Security and Defence Identity/Policy (ESDI/P)" // http://www.mfa.gov.tr/iv_-europeansecurity-and-defence-identity_policy-_esdi_p_.en.mfa (accessed July 10, 2010).

12 "Active Engagement, Modern Defence-Strategic Concept for the Defence and Security of the Members of the North Atlantic Treaty Organisation adopted by Heads of State and Government in Lisbon" (November 19, 2010) // http://www.nato.int/cps/en/natolive/official_texts_68580.htm (accessed January 9, 2011) (italics - SH).
} 
between NATO and EU constitutes the strongest wording among NATO's previous strategic concepts.

Despite the delicate balance created between NATO and EU on the participation of non-EU European Allies in CSDP, the practices prove that implementation of these modalities are not satisfactory. Lack of necessary involvement of any non-EU actor at the planning phase of any CSDP operation/mission, lack of consultations with both NATO and non-EU European NATO members prior to the launching of EULEX in Kosovo (January-February 2008), delays in the transmissions of Operation Plans of some operations such as EULEX, and lack of consultations with both NATO and non-EU European NATO members before the initiation of EUPOL in Afghanistan (June 2007) can be regarded as examples of failure to abide by the mentioned modalities. Non-EU NATO member Canada's position is worth noting here. This country emphasizes the importance of regular consultations for improving mission planning and coordination, the inclusion of third parties in the mission development process, the importance of joint training exercises and the necessity for systematic opportunities for feedback and sharing of lessons learned. Canadians also underline that in practice the EU has rarely included Canada at the planning stage. ${ }^{13}$

\section{Turkey's approach to the main problem}

Turkey is a staunch NATO Ally, and contributes significantly to the Alliance's political and military transformation, as well as to the operations. Most recently, on 27 March 2011, NATO Allies decided to take on the whole military operation in Libya under United Nations Security Council Resolution 1973. The purpose of Operation Unified Protector is to protect civilians and civilian-populated areas under threat of attack. It was decided that NATO will implement all military aspects of the UN Resolution. ${ }^{14}$ Turkey contributes to this operation. Turkey wants the NATO operation to be conducted efficiently, in line with the directives drawn out by the UN Security Council resolutions and accepted by consensus by the NATO Council. ${ }^{15}$

The main issue regarding the participation in the CSDP stems from the marginalization of Turkey's position during the process that the EU has been developing since the 1990s. Turkey believes that a successful security policy for any region can only be established with the inclusion of all the relevant actors. The issue is directly related with the transfer of the functions of the Western European

\footnotetext{
${ }^{13}$ Interview with a Canadian Diplomat (February 15, 2011).

14 "NATO and Libya - Operation Unified Protector" (April 2011) //

http://www.nato.int/cps/en/natolive/topics_71652.htm (accessed April 9, 2011).

15 "Speech Delivered by H.E. Prime Minister Recep Tayyip Erdoğan on Libya" (Ankara; April 7, 2011) // http://www.mfa.gov.tr/speech-delievered-by-h_e_-prime-minister-recep-tayyip-erdogan-on-libya_ankara_-7-april-2011_.en.mfa (accessed April 9, 2011).
} 
Union (WEU) to the European Union. The situation became more complicated when the EU expressed its desire to use NATO assets and capabilities for its operations within the framework of the ESDP. Turkey participated in the construction of the EU's security and defence identity within the framework of the WEU. As Ramazan Gozen points out, just like its application for accession to the EU, it applied for full membership in the WEU in 1991. Turkey was offered an 'associate membership'. The EU decided that full membership in the WEU would be contingent upon full membership in the EU. ${ }^{16}$

Turkey's status in the WEU system granted her the right to become closely involved in the European security architecture. Turkey had the right to participate in the meetings of the WEU Council and its working groups and subsidiary bodies under certain conditions. Turkey also had the right to speak and submit proposals, but not the right to block a decision that was the subject of consensus among the full member states; however, Turkey could adhere to such decisions later if she wanted. Turkey was also associated with the WEU Planning Cell and could nominate officers to the Cell. Moreover, Turkey could take part on the same basis as full members in WEU operations (as well as in exercises and planning) to which it committed forces. Turkey could also nominate Forces Answerable to the WEU (FAWEU) on the same basis. Therefore, by virtue of its NATO membership, it had a say in WEU operations, and it was directly involved in the planning and preparation of WEU operations in which NATO assets and capabilities were to be used within the framework of the Combined Joint Task Force. ${ }^{17}$

The efforts in the early years of the 1990s concentrated on the key role of the WEU and to that end WEU's reactivation as a connecter between NATO and the EU was regarded as the best option. In those days, the preference of the NATO member states was to develop a European Security and Defence Identity (ESDI) within the Alliance. In NATO's Strategic Concept of 1991, it was made clear that 'NATO would remain the essential forum for consultation among the Allies' (Art. 21). ${ }^{18}$ However, at the 1998 St. Malo Summit it was decided to establish a separate ESDP within the EU. Article 2 of the St. Malo Declaration emphasized that "the Union must have the capacity for autonomous action, backed up by credible military forces, the means to decide to use them and a readiness to do so, in order to respond to international crises." ${ }^{19}$ Throughout the development of the ESDP process the EU's decision making was limited to the EU's full members only, while

\footnotetext{
${ }^{16}$ Ramazan Gozen, Turkish Delicate Position between NATO and the ESDP (Ankara: Center for Strategic Research Papers, 2003), p. 25.

17 Ibid.: 26-27.

18 "NATO's 1991 Strategic Concept" //

http://www.nato.int/cps/en/natolive/official_texts_23847.htm (accessed June 13, 2010).

19 "Franco-British Summit Joint Declaration on European Defense" (Saint-Malo; December 4, 1998) // http://www.atlanticcommunity.org/Saint-Malo\%20Declaration\%20Text.html (accessed June 6, 2010).
} 
all others, irrespective of their importance, acquisitions and connections with the European security architecture, were put at the margin of the ESDP decision making mechanism. In short, the ESDP decision making mechanism created a structure that put EU members at the centre and the others at the margin, the latter serving only as "contributors" to the ESDP. ${ }^{20}$

Work has been carried out within NATO for the development of ESDI in parallel to the work in the EU for the Common European Security and Defense Policy (CESDP). NATO Allies at their Summit meeting held in Washington on 23-24 April 1999, through the documents accepted therein, have established the basis which takes into account Turkish expectations for full and equal participation of European Allies who are not, like Turkey, members of the EU, in the new structures to be established within the context of the CESDP. Following that period remarkable effort has been made for the acceptance of arrangements that would on this basis ensure Turkey's full and equal participation in the new structures. Turkish efforts have been intensified in the preservation and further development on a contractual basis of its acquis acquired at the WEU. ${ }^{21}$

Turkey is in close proximity to existing and potential crisis areas. Therefore, arrangements to be formulated for the security of Europe were of the utmost importance to it, given the fact that Turkey's vital interests would be at stake. The following aspects of EU activities are of particular significance to Turkey as outlined by Ambassador Omur Orhun:

Day to day consultations and other non-operational activities related to European security and defence issues; consultations on and the shaping of policy related to crisis situations, including the stage before a decision in principle on planning for or initiating an operation, full participation in all aspects of force planning, operational planning and exercises; not only military but also non-military crisis management operations. ${ }^{22}$

At the Helsinki Summit of 1999, Turkey's relations with the EU were at a historical crossroads. Turkey could have been marginalized and excluded from the emerging European project or there could be a working relationship to incorporate Turkey within in the European Union. The Helsinki Summit decided on the latter. According to Turkish authorities the declaration of Turkey as a candidate country on

\footnotetext{
20 Ramazan Gozen, supra note 16.

21 "Press Release of the Turkish Ministry of Foreign Affairs Regarding Common European Security And Defence Policy (CESDP) Addressed At The EU's Helsinki Summit No:239" (December 13, 1999) // http://www.mfa.gov.tr/press-release-regarding-common-european-security-and-defence-policy_cesdp_-addressed-at-the-eu_s-helsinki-summit_br_no_239--_december-13_-1999.en.mfa (accessed June 1, 2010).

22 Omur Orhun, "European Security and Defence Identity-European Security and Defence Policy: A Turkish Perspective," Perceptions Vol. 5 (September-November 2000) // http://www.sam.gov.tr/perceptions/Volume5/September-November2000/VolumeVN3OmurOrhun.pdf (accessed April 1, 2010).
} 
equal footing with other candidate countries was a positive development. Even before the Helsinki Summit when Turkey's candidate status was not yet 'confirmed politically' Turkey was giving its full support to ESDP. Turkish Defence Minister Sabahattin Cakmakoglu declared Turkey's readiness to contribute to the ESDI/P with five thousand troops, 36 F-16 planes, two transportation aircraft and a number of warships, and even more upon mutual agreement. ${ }^{23}$

Turkish officials underlined that it was foreseen at the Washington Summit that the involvement of the non-EU European Allies in EU-led crisis management operations would be ensured, building on the existing arrangements within the WEU. Turkey's approach regarding the evolving CESDP had been shaped within this framework. Turkey emphasized that the EU's requests from NATO will be assessed by Turkey within the framework of the above-mentioned principles, its national interests and of European security. Turkey's acceptance of an automatic EU access to NATO assets and capabilities was out of the question. Turkey made it clear that it cannot be expected to be content with the EU's relevant decisions and alter her own views. ${ }^{24}$ Therefore the 2000 Feira Council's conclusions were unacceptable for Turkey, mainly in terms of the participation issue, since in case of an EU operation undertaken with NATO assets, non-EU European NATO members would participate automatically 'if they so wish', whereas in the EU-only operations they would simply 'be invited' to be involved if the Council saw it appropriate. In Missiroli's words, the Helsinki and Feira decisions had indeed curtailed the "assured access" of European NATO allies to EU-only operations as compared to the arrangements in place within the WEU. In particular, their eventual 'invitation' to join was de facto subject to a unanimous decision, whereas their eventual participation in a WEU-only operation was assured unless 'a majority' of full members decided otherwise: the two procedures are indeed quite different. ${ }^{25}$ Turkey's main concerns stemmed from the fact that the position granted to non-EU NATO members was not satisfactory in the current phase when it was compared with those awarded by the WEU.

\footnotetext{
${ }^{23}$ Quoted from Mahmut B. Aykan, "Turkey and European Security and Defence Identity/Policy (ESDI/P): A Turkish View," Journal of Contemporary European Studies Vol. 13, No. 3 (December 2005): 337.

24 "Press Release of the Turkish Ministry of Foreign Affairs regarding the Decisions Taken at the EU Feira Summit (Unofficial Translation) No: 103" (June 20, 2000) // http://www.mfa.gov.tr/the-decisions-takenat-the-eu-feira-summit_br_-_unofficial-translation_br_no_103--_june-20_-2000.en.mfa (accessed July $19,2010)$.

${ }^{25}$ Antonio Missiroli, "EU-NATO Cooperation in Crisis Management: No Turkish Delight for ESDP," Security Dialogue (SAGE Publications) Vol. 33(1) (March 2002): 16.
} 


\section{ANALYZING THE INVOLVEMENT OF NON-EU EUROPEAN NATO MEMBERS IN CSDP THROUGH THE TURKISH EXPERIENCE}

\subsection{DIFFERENT INTERPRETATIONS OF THE NATO'S WASHINGTON SUMMIT COMMUNIQUÉ}

NATO's 1999 Washington Summit Communiqué is of significant importance in terms of the involvement of non-EU NATO Members in EU led operations. In essence, NATO's support for ESDP activities was linked to the fullest possible involvement of non-EU European Allies in ESDP activities through underscoring the modalities of the Western European Union. However, over the years the practices of the EU have been far from corresponding to this fact. Article 9 of the Washington Summit Communiqué underlined the importance of "mechanisms existing between NATO and the WEU (Art. 9.b)" and also "ensuring the fullest possible involvement of non-EU European Allies in EU-led crisis response operations (Art. 9.d)." ${ }^{26}$ Turkey gave utmost importance to these principles and throughout has sought compliance with the obligations as stated in the Communiqué.

From the Turkish perspective, the Washington consensus provided an important basis to its claims concerning the CSDP. As Turkey had an associate membership in the WEU, Turkey could participate in the strategic planning, operations and command of EU-led Petersberg type operations in its surrounding areas. Turkey had the right: 1 ) to take part in a WEU-led operation with NATO support, including its preparation and planning with full and equal rights; 2 ) to participate in an autonomous WEU operation with equal rights if it declared its readiness to take part by making available a significant troop contribution; and 3 ) to participate, as a member of both NATO and the WEU, in the organs the EU would set up, since NATO-EU mechanisms would be built on existing NATO-WEU mechanisms. The Washington Summit consensus recognized the WEU acquis as the basis of future work for the European security architecture. It accepted that the development of the ESDI would be constructed on the existing mechanisms of NATO-WEU cooperation. ${ }^{27}$ Turkey has kept reinforcing the point that it was foreseen at the Washington Summit that the involvement of the non-EU European Allies in EU-led crisis management operations would be ensured, building on the existing arrangements within the WEU.

However, the different approach of the EU in the interpretation of the Washington Summit Communique constituted a disagreement. The EU focused more on the Article 10 of the Washington Summit Communique, which reads:

26 "NATO's Washington Summit Communique," supra note 7.

${ }^{27}$ Ramazan Gozen, supra note 16: 40. 
We therefore stand ready to define and adopt the necessary arrangements for ready access by the European Union to the collective assets and capabilities of the Alliance, for operations in which the Alliance as a whole is not engaged militarily as an Alliance. ${ }^{28}$

Art. 10 stressed "assured EU access to NATO planning capabilities". Turkey has been looking at the picture by combining all the relevant official documents of both institutions. Turkey's arguments are based on Article 9 of the Washington Summit Communique and the NATO's Strategic Concept of 1999. The 1999 Strategic Concept unanimously underlines that the European Security and Defense Identity will continue to be developed within NATO and the decisions on making the Alliances' assets and capabilities available on a 'case by case basis', stating:

On a case-by-case basis and by consensus, to make its assets and capabilities available for operations in which the Alliance is not engaged militarily under the political control and strategic direction either of the WEU or as otherwise agreed, taking into account the full participation of all European Allies if they were so to choose (Article 30). ${ }^{29}$

Even though the Cologne European Council of 3-4 June 1999 confirmed the fact that the arrangements should be based on NATO's Washington Summit (by using the following wording: "Implementation of the arrangements based on the Berlin decisions of 1996 and the Washington NATO summit decisions of April 1999"), the arrangements of the EU that came afterwards were not in conformity with this understanding. The Helsinki and Feira decisions had also negatively affected the access of European NATO Allies to EU-only operations as compared to the arrangements in place within the WEU. The arrangements provided by EU's Nice Summit of 2000 were also short of satisfying the non-EU European Allies.

Turkey raised concern over bypassing the existing and agreed legal arrangements by the EU during the work of establishing the acquis for CSDP and particularly for the participation of non-EU European NATO members. In this vein, Turkey's efforts have concentrated on shaping a fair balance in the package agreement on the modalities of the cooperation between NATO and the EU. One should also bear in mind that these arrangements were not only benefiting Turkey, but the other non-EU European Allies as well.

\footnotetext{
28 "NATO's Washington Summit Communique," supra note 7.

29"The Alliance's Strategic Concept" (April 24, 1999) //

http://www.nato.int/cps/en/natolive/official_texts_27433.htm?selectedLocale=en (accessed July 7, 2010).
} 


\subsection{WHAT HAS HAPPENED ON THE OPERATIONS SIDE?}

As emphasized, Turkey has taken part in all of the Berlin Plus operations and all CSDP activities to which it has been invited. In fact, in many operations such as Proxima in Macedonia or EUPM in Bosnia Herzegovina, Turkey has contributed more than most EU members. ${ }^{30}$ Turkey is still the largest non-EU contributor to CSDP missions and operations. Despite Turkey's extensive contributions to the operations either with Berlin Plus or autonomous EU operations, the modalities of these arrangements have not been completely implemented. As Kiziltan puts forward from the Turkish perspective, the application of Nice Implementation Document has unfortunately not lived up to expectations as a major breakthrough in relations with the EU. The EU has either applied it in a perfunctory manner or essentially ignored it. For example, not even symbolic consultations were held with Turkey when "EUJUST LEX" was launched in Iraq or "EUJUST Themis" in Georgia, as would have been possible under the provision of this document regarding EU operations conducted in geographic proximity of non-EU NATO members or that may affect their national security interests. ${ }^{31}$ However the practices of the EU in fact have been far from complying with the agreed arrangements, since Art. 12 of the Nice Implementation Document reads:

In a specific case when any of the non-EU European Allies raises its concerns that an envisaged autonomous EU operation will be conducted in the geographic proximity of a non-EU European Ally or may affect its national security interests, the Council will consult with that Ally and, taking into consideration the outcome of those consultations, decide on the participation of that Ally. ${ }^{32}$

During the initial stages of the crisis in Georgia, Turkey requested to have immediate consultations with the EU; however it did not receive a favourable reply at the time. EUJUST THEMIS, which was designed to support the Georgian authorities in addressing urgent challenges, was an operation taking place in one of the neighbouring countries of Turkey. Similarly, Turkey's offer to support an autonomous civilian monitoring mission in Georgia (EUMM) in 2008 was also not accepted. The civilian crisis management operation EUJUST LEX launched in Iraq in 2005 is also taking place at the immediate vicinity of Turkey. However, there was a lack of response to Turkey's request to contribute to this mission, as well. Turkey's request to be involved in the CSDP decision making phase was fully in line with Article 12 of the Nice Implementation Document as stated above. These are clear examples of narrow interpretations by the EU vis-à-vis a non-EU NATO member

30 "European Security and Defence Identity/Policy (ESDI/P)", supra note 11.

${ }^{31}$ Ihsan Kiziltan, supra note 5: 36.

32 "ESDP: 'Implementation of the Nice Provisions on the Involvement of the Non-EU European Allies'," supra note 9. 
showing a strong determination to support CSDP activities. The EU's arguments on not consulting Turkey were rather difficult to understand. These arguments were mainly that the aforementioned activities are civilian operations and in accordance with the consultation arrangements only military operations can be consulted. In fact, the arrangements that established the acquis of the NATO-EU cooperation did not differentiate between civilian or military operations; they apply to all sorts of operations.

It is not only Turkey who is putting these arguments forward, but also NATO's top official Rasmussen was quoted by the Danish press on July 7, 2010 that he finds it unfair that the Turks are not included in the decisions on the EU's peace operation in Bosnia-Herzegovina since they participate there, too. NATO's Secretary General stated that "Turkey is the second largest contributor to the EU's operation in Bosnia, but Turkey is not included in the decision making process. That is unfair. The EU should clearly signal that Turkey belongs to the western circle". ${ }^{33}$ In the same news, EUFOR's spokesman Major Bruce Foster is also quoted as saying: "Turkey is an important partner that is fully involved in a number of areas in the operation" ${ }^{34}$.

During 2007 the issues concerning NATO-EU cooperation in Kosovo and Afghanistan have been frequently discussed. At the time, some commentators in the international press claimed that these problems emanate from the blockages laid down by Turkey. An example was the article published in the International Herald Tribune on August 23, 2007 that read:

Neither EU police officers nor the Afghan police will be automatically given intelligence or backup support from NATO if they come under attack from the Taliban or other fighters. The reason is a squabble in Brussels between the EU and Turkey, a NATO member. ${ }^{35}$

Turkey, being among the leading NATO members in terms of its contributions to NATO operations assumed in Kosovo and Afghanistan, had no intention to block NATO-EU cooperation within the context of those EU civilian ESDP missions planned in Kosovo or in Afghanistan. In fact, Turkey has stressed that the EU civilian missions could play an important complementary role in terms of contributing to the success of the NATO missions conducted in those regions. It is with this understanding that Turkey, let alone impeding cooperation between the two organizations, advocates the rapid conclusion of the necessary arrangements which would enable a more effective relationship between NATO and the EU. In those

\footnotetext{
33 Thomas Lauritzen, "Fogh Defends Turkey: The EU is not Being Fair," Politiken (July 7, 2010).

34 Ibid.

35 Judy Dempsey, "Letter from Germany: Bickering between NATO and EU Hampers Training of Afghan Police," International Herald Tribune (August 23, 2007).
} 
days Turkey frequently reminded its expectation from its Allies and the EU Member States of the adherence to decisions taken and arrangements laid down at the highest level for such cooperation. ${ }^{36}$ In fact, Turkey has never wished to hinder NATO-EU cooperation in Kosovo and Afghanistan, but has continually underscored the need for abiding by agreed decisions and commitments as necessary.

\subsection{TURKEY'S EXCLUSION FROM EUROPEAN DEFENCE INDUSTRY COOPERATION PROJECTS}

A striking aspect of the matter is related to Turkey's exclusion from European defence industry cooperation projects. The main EU institution in this respect, European Defence Agency (EDA), was established on the basis of the acquis of the Western European Armaments Group/Organisation (WEAG/WEAO). Turkey and Norway, as associate members of the WEU, were full members of the WEAG/WEAO. Norway and Turkey approved the transfer of responsibilities and institutional acquis of the WEAG/WEAO on the condition that they would be included in the European defence industry projects to be handled by the EDA. The EU, through its Joint Action establishing the EDA, acknowledged this commitment. The draft text on Turkey has been blocked since 2005, while Norway was able to finalize these arrangements.

EDA was established under a Joint Action of the Council of Ministers on 12 July, 2004, with a view to supporting the Member States and the EU Council in their effort to improve European defence capabilities. Article 8 of the preface of the "Council Joint Action 2004/551/CFSP of 12 July 2004" on the establishment of the European Defence Agency reads as:

The Agency should develop close working relations with existing arrangements, groupings and organisations such as Letter of Intent (LoI), Organisation de coopérationconjointe en matière d'armement (OCCAR) and Western European Armaments Group (WEAG)/Western European Armaments Organisation (WEAO), with a view to assimilation or incorporation of relevant principles and practices as appropriate. ${ }^{37}$

Turkey is aware that it cannot participate with full membership rights in EDA, prior to the realization of the country's full membership in the EU. However upon the legal commitment of the EU as underlined in the Council Joint Action Plan

\footnotetext{
36 "QA: 42; Statement of the Spokesman of the Ministry of Foreign Affairs of Turkey, in a Response to a Question (Unofficial Translation)" (December 3, 2007) // http://www.mfa.gov.tr/_p_qa_42--_3december-2007__statement-of-the-spokesman-of-the-ministry-of-foreign-affairs-of-turkey_-in-aresponse-to-a-question-_unofficial-translation____p_.en.mfa (accessed July 19, 2010).

37 "Council Joint Action 2004/551/CFSP of 12 July 2004 on the establishment of the European Defence Agency" // http://eur-lex.europa.eu/LexUriServ/site/en/oj/2004/I_245/I_24520040717en00170028.pdf, (accessed June 17, 2010) (italics - SH).
} 
establishing EDA, Turkey gave its consent to the closure of WEAG\WEAO for establishing working relations on the basis of existing arrangements. At the time when the 'Administrative Arrangement Document' was about to enter into force together with the document prepared for Norway, on April 14, 2005 the Greek Cypriot Administration prevented the approval of Turkey's document by emphasizing that this decision was a result of political considerations. However, Norway was able to finalize these arrangements. Since 2005 Turkey's efforts on the way to finalizing its arrangements with EDA have been futile, as a result of blockage by one EU member.

The Joint Action Plan on EDA not only refers to the WEAG acquis in the preface, but also to the Article 6 of the Chapter VI on "relations with third countries, organisations and entities". This Article reads:

The non-EU WEAG members shall be provided with the fullest possible transparency regarding the Agency's specific projects and programmes with a view to their participation therein as appropriate. A consultative committee shall be set up for this purpose, to provide a forum for exchanging views and information on matters of common interest falling within the scope of the Agency's mission. ${ }^{38}$

The partial treatment of Turkey in terms of EDA has been raised by Turkish officials in many possible platforms. As such, former Turkish Minister of Foreign Affairs Ali Babacan's stated at the European Parliament Committee of Foreign Affairs in Brussels on May 28, 2008:

We are being blocked away from European Defence Agency, security arrangements with EU and this is happening by one member's opposition, by one member's veto in a way, although this implementation protocol says that non-EU European countries should be involved more in the security issues, defence issues of the European Union; Turkey is kept away. ${ }^{39}$

NATO Secretary General Rasmussen also rejects treating Turkey unfairly on this matter. He was quoted in Politiken newspaper as saying:

I actually think it is unfair. Norway, which is not a member of the EU either, has an agreement with the European Defence Agency. Why can't Turkey have that? I do not see any explanation and did not either when I was Prime Minister. ${ }^{40}$

On this matter comments by Nick Witney, former chief executive of EDA, are also remarkable and thought provoking:

\footnotetext{
38 Ibid.

39 "Speech Delivered by H.E. Ali Babacan, Foreign Minister of Turkey at the European Parliament Committee on Foreign Affairs" (Brussels; May 28, 2008) // http://www.mfa.gov.tr/speech-delivered-byh_e_-ali-babacan_foreign-minister-of-turkey-at-the-european-parliament-committee-on-foreignaffairs_-28-may.en.mfa (accessed July 10, 2010).

40 Thomas Lauritzen, supra note 33.
} 
We initiated parallel negotiations with Turkey and Norway because almost all EU countries wanted this. But then Cyprus entered the EU and blocked everything. We were all very frustrated. It has been like that ever since. The Cypriots run around and close all doors and windows to the Turks. It is scandalous and selfish, and it is bad for the EU. But things are not going to change before someone deals with Cyprus. ${ }^{41}$

Witney's remarks bluntly describe the current stalemate. However, high level officials' remarks and complaints do not change anything, so long as these discourses are not put into practice. The Greek Cypriot Administration did not become a full member to the EU automatically; it was a result of the consensus reached by all the EU members. The consequences of accepting the Greek Cypriots as an EU member before the Cyprus problem was resolved had to be considered with due care and caution; unfortunately at the time this was not the case. Now not only Turkey, but the entire EU itself is faced with these negative consequences. In essence, the overall picture explained above in terms of establishing the necessary link between EDA and Turkey clearly shows that there is not any genuine institutional impediment in the way. The current impasse is simply the result of Greek Cypriots' objection and purely political.

\subsection{WHY CAN TURKEY NOT CONCLUDE A SECURITY AGREEMENT WITH THE EU?}

Another example of the approach of the EU in terms of the involvement of non-EU Allies in CSDP is the prevention of the conclusion of a permanent security agreement between Turkey and the EU. Such agreements provide the necessary guarantees for the protection of EU classified information released to third parties relating to any area of the Union's activity. The EU has concluded specific agreements more limited in scope with a number of third countries. These agreements may be concluded for an indefinite period (such as framework participation agreements with third States taking part in EU-led ESDP crisis management operations) or on a temporary or ad hoc basis. ${ }^{42}$ Turkey concluded ad hoc agreements or arrangements of limited duration with the EU that will allow the exchange of EU classified information in specific operational contexts to which Turkey has been contributing. However, the permanent security agreement on the exchange of classified information has not been realized.

\footnotetext{
${ }^{41}$ Ibid.

42 "Information Note of the General Secretariat of the Council on 'Exchange of EU classified information (EUCI) with third countries and Organizations'" (Brussels; September 8, 2006) // http://www.statewatch.org/news/2006/sep/eu-classified-docs-third-countries.pdf (accessed July 17, 2010).
} 
Turkey has been a non-EU NATO member negotiating for accession to the EU since 2005. To this end, the problem related to the exchange of classified information with the EU due to a lack of Security Agreement between Turkey and the EU does not follow this logic. The draft agreement is ready, but blocked within the EU due to political reasons. As Kiziltan states, the blockage on the agreement regarding classified information is hampering not only Turkish-CSDP ties, but also relations between Turkey and the EU in general, including in scientific and technological cooperation. Despite previous EU decisions, such as the EU's Joint Action of 2004 on establishing EDA, to conclude these agreements with Turkey the EU approval process has been blocked. Failure to meet its own obligations does not bring any credibility to the EU. ${ }^{43}$ This blockage is also not in conformity with the Nice Implementation document and it points out once again that the agreed framework of the Berlin Plus is 'narrowly and selectively' interpreted by the EU.

The reason why Turkey cannot conclude a security agreement with the EU is also result of the blockage of the Greek Cypriots. This unfair treatment has been raised not only by Turkey, but by other European officials as well. NATO Secretary General Rasmussen was quoted by 'Euobserver' in May 2010 as saying:

Speaking frankly, maybe a bit bluntly, the EU must move to accommodate some concerns raised by NATO allies that are not EU members. The EU should include non-EU contributors to the military decision-making process, it should conclude a security agreement with Turkey and an arrangement between Turkey and the European Defence Agency. ${ }^{44}$

The NATO Chief shared his opinion also at a transatlantic security conference in Brussels in March 2010: "Turkey is the second-largest contributor to the EU operation in Bosnia ... but the EU does not provide non-EU contributors with the opportunity to contribute to policy and decision-making. ${ }^{\prime \prime 5}$ It is argued that the lack of security agreement between Turkey and the EU has been affecting the NATO-EU cooperation negatively, mainly on the ground in terms of the operations.

\footnotetext{
${ }^{43}$ Ihsan Kiziltan, supra note 5: 44-45.

${ }^{44}$ Valentina Pop, "NATO Chief Tells EU to Reach Security Pact with Turkey" // http://euobserver.com/13/30134 (accessed July 17, 2010).

45 "NATO chief Urges EU to Bring Turkey into Defence Arm" //

http://www.eubusiness.com/news-eu/nato-defence-turkey.3wk/ (accessed July 17, 2010).
} 


\section{THE CASES RELATED WITH NATO-EU COOPERATION}

\subsection{REFLECTIONS OF THE DIFFERENT WORKING CULTURES OF THE} EU AND NATO

It is clear that there is a need for improving NATO-EU cooperation, since they both share the same values and make efforts to contribute to international peace, security and stability. They are mostly involved in the same operation theaters and they also have 21 members in common. They face the same nature of the risks, threats and challenges. The capabilities they require are most of the time compatible. Strengthening NATO-EU cooperation is necessary in more strongly handling the current challenges together.

Existing discrepancies in the degree of openness and transparency accorded by the two organizations constitute the core of the issue. The practices of NATO and the EU reveal that NATO is more open to working with non-NATO contributors. Current problems in the NATO-EU cooperation are mainly stemming from the restrictive working culture of the EU, which should be addressed with a comprehensive approach. The starting point could be to discuss the main working parameters and philosophies of these two organizations. NATO's transparent and open policies vis-à-vis its counterparts are obvious and the ramifications of this constructive approach are visible both in practice and the documents, such as NATO's Comprehensive Approach Document. More specifically, NATO has taken a more eager stance on working with the EU. As anecdotal evidence, this seems to be reflected in the number and significance of references made to the EU and to NATO-EU cooperation in NATO declarations and documents. Also EU officials are regularly invited to attend more NATO events than vice versa. ${ }^{46}$

NATO seems to be more willing to transform its structures and practices to bring force-contributing partners closer to the Alliance. As such, the requests by EU partners of NATO for deeper consultations with NATO reveals the wish for closer involvement in CSDP on the part of Allies that are not in the EU. ${ }^{47}$ NATO's 'PoliticalMilitary Framework (PMF) for NATO-led PfP Operations' Document is also clear proof of the Alliance's open and transparent approach. The purpose of the PMF Document is stated as follows:

To establish a political-military framework for NATO-led PfP operations to enable Partners to participate in the planning and execution of PfP activities as closely as is practically feasible and to ensure that Partners joining future NATO-led PfP operations be afforded appropriate opportunities to contribute to the provision of

\footnotetext{
${ }^{46}$ Ihsan Kiziltan, supra note 5: 37.

${ }^{47}$ Ibid.
} 
political guidance for and oversight over such operations ... The main aim of this framework is to set out principles, modalities and other guidance for Partner involvement in political consultations and decision making, in operational planning and in command arrangements. ${ }^{48}$

On February 8, 2010 the North Atlantic Council agreed that the Political Military Framework for NATO-led PfP Operations (PMF) applies to all countries which are recognized by the Council as potential and actual non-NATO contributing nations in the context of a NATO-led operation, in the consultation, planning and execution phases of that operation. ${ }^{49}$ The abovementioned document is reviewed annually in order to be able to enhance the involvement of partners and to work on the possible shortcomings through taking into account of the Partners opinions. NATO is regularly revising its own modalities with a very transparent and open approach. However, the same exercises are not taking place on the EU's side. In fact, the EU is failing to comply with its own arrangements in terms of involving non-EU Allies. As an outcome of this approach revision of the existing mechanisms are not taking place on the EU's side.

Another striking difference is in terms of bringing together the political wills of member states of each organization. On NATO's side, reaching consensus is generally smooth and well functioning. However this is not the case at the EU's end. There is a discrepancy between the EU's stated ambition and its actual policies. Javier Solana's decade as the High Representative for the Common Foreign and Security Policy demonstrates that personality matters, as do institutions. But neither will make up for a lack of political will on the part of member states. For example the disagreements between the EU's member states over Iraq made it impossible to form a united EU policy. The EU decision-makers stepped back from the big questions and instead focused on the areas where the EU could make a difference. This has led to missions that are often limited in scope and time, in the western Balkans, in Africa, but also in Aceh (Indonesia) and Georgia. The Lisbon Treaty could serve as an opportunity to be exploited in the abovementioned matters. Treaty-based authority, including a right of initiative and a foothold in the European Commission, plus much more staff and financial resources will definitely make a difference. The Lisbon Treaty could be a useful tool in terms of closing the gap between ambition and achievement. ${ }^{50}$ There were many times that Solana was

\footnotetext{
48 "Political-Military Framework for NATO-led PfP Operations" // http://www.nato.int/cps/en/natolive/official_texts_27434.htm (accessed July 17, 2010). ${ }^{49}$ Ibid.

50 "What the EU Can Learn from Solana's Legacy," European Voice (December 1, 2009) // http://www.europeanvoice.com/article/imported/what-the-eu-can-learn-from-solana-slegacy/66524.aspx (accessed February, 20 2011).
} 
touching upon the importance of the political will of member states and making remarks such as:

Our Member States each have a different history and geography. We must improve our ability to channel the richness of this diversity in support of our political engagement in other parts of the world. ... EU foreign policy cannot function if it is only about Member States particular concerns. We need solidarity. Also in political terms. We should back a Member State if it has a particular problem or need. But this is a two-way street. Individual solidarity with the common endeavour is key for projecting force, for making ESDP works. ${ }^{51}$

The issue of achieving solidarity has been high on the EU's agenda, whereas at NATO solidarity clause constitutes the backbone of the Alliance's decisions and actions. The working rationales of the two organizations are different at this junction, as well. Lack of political will of the member states is reflected in the EU's common policies, as well as in NATO-EU relations. Once the EU starts to take bigger steps in achieving solidarity in political terms, its positive ramifications over the NATO-EU cooperation will be visible as well.

\subsection{NATO-EU COOPERATION AND THE CYPRUS QUESTION}

"Berlin plus" arrangements and the implementation thereof apply only to those EU Member States which are also either NATO members or parties to the "Partnership for Peace (PfP)" and which have consequently concluded bilateral security agreements with NATO. Greek Cypriot Administration is not a PfP member and does not have a security agreement with NATO on the exchange of classified documents; therefore it cannot participate in official NATO-EU meetings. However, informal meetings are occasionally organized. As things stand, Greek Cypriots' participation in these arrangements is out of question for Turkey, and Turkish officials strongly raise their objections to the concessions asked from them in terms of diluting the existing framework.

It is a fact that the difficulties in the current state of affairs in NATO-EU cooperation are also related to the Cyprus problem. The decision of the EU to accept the Greek Cypriot Administration as a member in 2004 put the Cyprus question in the middle of the delicate balance established between NATO and EU, and brought about other significant complications as well. However, the Cyprus issue is definitely not the only obstacle on the way to moving NATO-EU relations

51 "Remarks by Javier Solana, EU High Representative for the Common Foreign and Security Policy 'ESDP@10: What lessons for the future?'" (Brussels; July 28, 2009) // http://www.consilium.europa.eu/uedocs/cms_data/docs/pressdata/EN/discours/109453.pdf (accessed July 19, 2010). 
further. Therefore blaming Turkey for blocking NATO-EU cooperation is without foundation.

A historical opportunity was missed when Greek Cypriots voted against the UN Plan of 2004. The Ministry of Foreign Affairs of Turkey pointed at it in a statement on May 1, 2004:

The referenda were held in Cyprus on 24 April 2004 and overwhelming majority of Turkish Cypriots voted in favor of the UN Secretary-General's settlement plan which would have allowed for a united Cyprus to join the EU on 1 May 2004. However, the Greek Cypriots rejected it with a 75 percent majority, and efforts to allow a unified Cyprus to join the EU thus failed. ${ }^{52}$

Even though the EU appreciated the fact that the Turkish Cypriot side voted 'yes' to the Annan Plan, this did not change the negative consequences of accepting the Greek Cypriots into the EU. Through this decision, the EU has officially incorporated the impasse into its structures and has somehow become party to the Cyprus question. The European Commission pointed out in its press release of April 24, 2004:

The European Commission deeply regrets that the Greek Cypriot community did not approve the comprehensive settlement of the Cyprus problem. A unique opportunity to bring about a solution to the long-lasting Cyprus issue has been missed. The European Commission would like to warmly congratulate Turkish Cypriots for their 'Yes' vote. This signals a clear desire of the community to resolve the island's problem. ${ }^{53}$

This 'deep regret' of the EU has not been reflected in practice since 2004. Turkey is convinced that a comprehensive solution under a UN umbrella will definitely bear positively on NATO-EU relations.

\subsection{READING THE CONCEPT OF NATO-EU COOPERATION DIFFERENTLY}

The actual scope of NATO-EU relations are interpreted differently by the two sides. The decisions taken in December 2002 on the EU side did not match those made in the Alliance. These discrepancies between the decisions taken by the two organizations constitute the crux of the dispute. NATO-EU strategic cooperation, in accordance with the letter and spirit of the agreed framework, covers all aspects of

\footnotetext{
52 "Press Release of the Ministry of Foreign Affairs of Turkey Regarding the EU Enlargement" (May 1, 2004) // http://www.mfa.gov.tr/no_73---press-release-regarding-the-eu-enlargement_-1-may2004.en.mfa (accessed July 13, 2010).

53 "What the World said After the Referanda," The European Commission's Press Release (April 24, 2004) // http://www.mfa.gov.tr/what-the-world-said-after-the-referanda.en.mfa (accessed July 13, 2010).
} 
ties between NATO and the EU. ${ }^{54}$ In fact, the 2003 agreement between NATO and the EU was established on the basis of 1999 Strategic Concept and Washington Summit Communiqué. Therefore, it covers not only the Berlin Plus operations, but also the entire strategic cooperation. It is argued that the agreed modality of cooperation between NATO and the EU applies solely to Berlin Plus Operations conducted by the EU with recourse to NATO assets and capabilities. However, this understanding ignores the fact that the nature of support NATO may provide to any given CSDP undertaking is the same; it is not only about operations. The EU has a narrower definition of the scope of NATO-EU cooperation. The EU insists that this can be restricted only in cases when the "Berlin plus" arrangements are employed. In other words, the EU believes that all EU members, including the Greek Cypriots, must participate in all other avenues of interaction between NATO and the EU. As a result of the EU's obstinacy on this point, formal meetings between the North Atlantic Council and the EU's Political and Security Committee (i.e. without the participation of the Greek Cypriots now, and before Maltese representatives) are essentially limited to a single item, namely, the Berlin Plus operations. The EU insists that other topics can be dealt with at NAC-PSC meetings only in the presence of the Greek Cypriots at the moment. Proposals put forward at various times by Turkey and other Allies to informally discuss issues such as terrorism, Darfur and Hurricane Katrina have thus not been accepted. ${ }^{55}$

\section{CONCLUSIONS}

This article attempts to answer the question of whether the modalities of involving non-EU European NATO members in CSDP activities have been fulfilled. Through dwelling on the relevant official documents and their implementation, I have reached the conclusion that the compliance with the modalities for involving a non-EU European NATO member like Turkey in CSDP activities has not been satisfactory. The non-EU European NATO members' experience in their relations with the EU is not in conformity with the experience of NATO's partners in terms of the openness and transparency accorded by NATO. Non-EU Allies like Turkey wish to take part in the negotiation of key documents in the EU, when it comes to the activities they participate in. This happens not to be the case, despite the letter and spirit of written obligations on the part of the EU to involve non-EU European NATO members in CSDP activities to the fullest extent.

Non-EU Allies fullest involvement in CSDP activities is the cornerstone of NATO-EU cooperation. The EU's restrictive approach to involving non-EU NATO

\footnotetext{
${ }^{54}$ Ihsan Kiziltan, supra note 5: 41.

${ }^{55}$ Ibid.
} 
members has affected this relationship negatively. Since 2001 considerable progress has been made in developing the NATO-EU strategic partnership. However its full potential has yet to be realized. Current problems in the NATO-EU cooperation mainly stem from the restrictive working culture of the EU.

Since the beginning of the institutionalization of the CSDP, the issue of NonEU Allies' fullest involvement has been a significant aspect of this process. It will not be realistic to look for efficient cooperation between NATO and the EU when commitments toward non-EU Allies are not fulfilled. I am of the view that many of the current shortcomings of this cooperation mainly stem from the different working cultures of both organizations - NATO is more open to engagement towards non-members, whereas the EU is still working on adopting a more transparent attitude when dealing with non-EU European members. At this stage, concentrating on compliance with the existing arrangements on participation of non-EU NATO members in CSDP activities and implementing them duly will definitely make a difference and will serve the best interests of all parties involved.

\section{BIBLIOGRAPHY}

1. Aykan, B. Mahmut. "Turkey and European Security and Defence Identity/Policy (ESDI/P): A Turkish View." Journal of Contemporary European Studies Vol. 13, No. 3 (December 2005): 335-359.

2. Dagand, Sophie. "The impact of the Lisbon Treaty on CFSP and ESDP." European Security Review No. 37 (March 2008) //

http://www.isis-europe.org/pdf/2008_artrel_150_esr37tol-mar08.pdf (accessed April 17, 2011).

3. Dempsey, Judy. "Letter from Germany: Bickering between NATO and EU Hampers Training of Afghan Police." International Herald Tribune (August 23, 2007).

4. Drent, Margriet, and Dick Zandee. Breaking Pillars: Towards a Civil-Military Security Approach For the European Union. Netherlands: Cligendeal Institute, $2010 / /$

http://www.clingendael.nl/publications/2010/20100211_breaking_pillars.pdf (accessed April 17, 2011).

5. Gozen, Ramazan. Turkish Delicate Position between NATO and the ESDP. Ankara: Center for Strategic Research Papers, 2003.

6. Kiziltan, Ihsan. "Improving the NATO-EU Partnership: A Turkish Perspective." Turkish Policy Quarterly Vol. 7, No. 3 (2008): 33-46. 
7. Lauritzen, Thomas. "Fogh Defends Turkey: The EU is not Being Fair." Politiken (July 7, 2010).

8. Missiroli, Antonio. "EU-NATO Cooperation in Crisis Management: No Turkish Delight for ESDP." Security Dialogue (SAGE Publications) Vol. 33(1) (March 2002): 9-26.

9. Pop, Valentina. "NATO Chief Tells EU to Reach Security Pact with Turkey" // http://euobserver.com/13/30134 (accessed July 17, 2010).

10. "NATO-EU: a Strategic Partnership" // http://www.nato.int/cps/en/natolive/topics_49217.htm (accessed July 1, 2010).

11. "Statement by H.E. Mr. İsmail Cem June 26, 2001 - Luxembourg" // http://www.mfa.gov.tr/_p_statement-by-h_e_-mr_-ismail-cem_br_june-26_2001-luxembourg_p_.en.mfa (accessed July 19, 2010).

12. "ESDP: 'Implementation of the Nice Provisions on the Involvement of the Non-EU European Allies'." The Brussels European Council, Presidency Conclusions, Annex II (October 24-25, 2002).

13. "European Security and Defence Identity/Policy (ESDI/P)" // http://www.mfa.gov.tr/iv_-european-security-and-defence-identity_policy_esdi_p_.en.mfa (accessed July 10, 2010).

14. "Active Engagement, Modern Defence-Strategic Concept for the Defence and Security of the Members of the North Atlantic Treaty Organisation adopted by Heads of State and Government in Lisbon" (November 19, 2010) // http://www.nato.int/cps/en/natolive/official_texts_68580.htm (accessed January 9, 2011).

15. "NATO and Libya - Operation Unified Protector" (April 2011) // http://www.nato.int/cps/en/natolive/topics_71652.htm (accessed April 9, 2011).

16. "Speech Delivered by H.E. Prime Minister Recep Tayyip Erdoğan on Libya" (Ankara; April 7, 2011) //

http://www.mfa.gov.tr/speech-delievered-by-h_e_-prime-minister-receptayyip-erdogan-on-libya-_ankara_-7-april-2011_.en.mfa (accessed April 9, 2011).

17. "NATO's 1991 Strategic Concept" // http://www.nato.int/cps/en/natolive/official_texts_23847.htm (accessed June 13, 2010).

18. "Franco-British Summit Joint Declaration on European Defense" (Saint-Malo; December 4, 1998) // http://www.atlanticcommunity.org/Saint-Malo\%20Declaration\%20Text.html 
(accessed June 6, 2010).

19. "Press Release of the Turkish Ministry of Foreign Affairs Regarding Common European Security And Defence Policy (CESDP) Addressed At The EU's Helsinki Summit No: 239" (December 13, 1999) //

http://www.mfa.gov.tr/press-release-regarding-common-european-securityand-defence-policy-_cesdp_-addressed-at-the-eu_s-helsinkisummit_br_no_239--_december-13_-1999.en.mfa (accessed June 1, 2010).

20. Orhun, Omur. "European Security and Defence Identity-European Security and Defence Policy: A Turkish Perspective." Perceptions Vol. 5 (SeptemberNovember 2000) // http://www.sam.gov.tr/perceptions/Volume5/September November2000/VolumeVN3OmurOrhun.pdf (accessed April 1, 2010).

21. "Press Release of the Turkish Ministry of Foreign Affairs regarding the Decisions Taken at the EU Feira Summit (Unofficial Translation) No: 103" (June 20, 2000) //

http://www.mfa.gov.tr/the-decisions-taken-at-the-eu-feira-summit_br__unofficial-translation_br_no_103--_june-20_-2000.en.mfa (accessed July 19, 2010).

22. "NATO's Washington Summit Communiqué" (April 24, 1999) // http://www.nato.int/docu/pr/1999/p99-064e.htm (accessed June 13, 2010).

23. "The Alliance's Strategic Concept" (April 24, 1999) // http://www.nato.int/cps/en/natolive/official_texts_27433.htm?selectedLocale =en (accessed July 7, 2010).

24. "QA: 42; Statement of the Spokesman of the Ministry of Foreign Affairs of Turkey, in a Response to a Question (Unofficial Translation)" (December 3, 2007) // http://www.mfa.gov.tr/_p_qa_42--_3-december-2007__-statementof-the-spokesman-of-the-ministry-of-foreign-affairs-of-turkey_-in-aresponse-to-a-question-_unofficial-translation_-__p_.en.mfa (accessed July 19, 2010).

25. "Council Joint Action 2004/551/CFSP of 12 July 2004 on the Establishment of the European Defence Agency" // http://eurlex.europa.eu/LexUriServ/site/en/oj/2004/I_245/I_24520040717en00170028. pdf (accessed June 17, 2010).

26. "Speech Delivered by H.E. Ali Babacan, Foreign Minister of Turkey at the European Parliament Committee on Foreign Affairs" (Brussels; May 28, 2008) // http://www.mfa.gov.tr/speech-delivered-by-h_e_-ali-babacan_-foreignminister-of-turkey-at-the-european-parliament-committee-on-foreignaffairs_-28-may.en.mfa (accessed July 10, 2010). 
27. "Information Note of the General Secretariat of the Council on 'Exchange of EU classified information (EUCI) with third countries and Organizations'" (Brussels; September 8, 2006) //

http://www.statewatch.org/news/2006/sep/eu-classified-docs-thirdcountries.pdf (accessed July 17, 2010).

28. "NATO Chief Urges EU to Bring Turkey into Defence Arm" // http://www.eubusiness.com/news-eu/nato-defence-turkey.3wk/ (accessed July 17, 2010).

29. "Political-Military Framework for NATO-led PfP Operations" // http://www.nato.int/cps/en/natolive/official_texts_27434.htm (accessed July 17, 2010).

30. "What the EU Can Learn from Solana's Legacy." European Voice (December 1, 2009) // http://www.europeanvoice.com/article/imported/what-the-eu-canlearn-from-solana-s-legacy/66524.aspx (accessed February 20, 2011).

31. "Remarks by Javier Solana, EU High Representative for the Common Foreign and Security Policy 'ESDP@10: What lessons for the future?'" (Brussels; July $28,2009) / /$

http://www.consilium.europa.eu/uedocs/cms_data/docs/pressdata/EN/discour s/109453.pdf (accessed July 19, 2010).

32. "Press Release of the Ministry of Foreign Affairs of Turkey Regarding the EU Enlargement" (May 1, 2004) // http://www.mfa.gov.tr/no_73---press-release-regarding-the-euenlargement_-1-may-2004.en.mfa (accessed July 13, 2010).

33. "What the World Said After the Referanda." The European Commission's Press Release (April 24, 2004) // http://www.mfa.gov.tr/what-the-world-said-afterthe-referanda.en.mfa (accessed July 13, 2010). 